\title{
THE ATTACK of Rastrococcus sp. (HEMIPTERA: PSEUDOCOCCIDAE) ON Dysoxylum mollissimum Blume IN CAMPUS FOREST OF BENGKULU UNIVERSITY
}

\author{
Sempurna Ginting ${ }^{1}$, Efratenta Katherina Depari ${ }^{2}$, Nadrawati ${ }^{3}$, \& Agustin Zarkani $^{3}$ \\ ${ }^{1,3}$ Department of Plant Protection, Faculty of Agriculture, University of Bengkulu, Indonesia \\ ${ }^{2}$ Department of Forestry, Faculty of Agriculture, University of Bengkulu, Indonesia \\ Jl. W.R Supratman, Kandang Limun Bengkulu 38371 \\ E-mail: sempurnaginting@unib.ac.id
}

Manuscript received: 25 November 2019. Revision accepted: 27 February 2020

\begin{abstract}
The attack of Rastrococcus sp. (Hemiptera: pseudococcidae) on Dysoxylum mollissimum Blume in campus forest of Bengkulu University. Dysoxylum mollissimum is a commodity that is widely used as carpentry wood and furniture in Bengkulu. Rastrococcus sp. is one of the pests of D. mollissimum. The purpose of this study was to evaluate the attack of Rastrococcus sp. on saplings, poles and trees D. mollissimum in the campus forest of Bengkulu University. The study was conducted with a purposive sampling survey method. The observational variables were symptoms and the rate of attack of Rastrococcus sp. at various stages of growth, the host range, and the identification of natural enemies of Rastrococcus sp. The results showed that Rastrococcus sp. was able to attack D. mollissimum at all growing stages, namely sapling, pole and tree. The highest number of Rastrococcus sp. population was observed in the pole phase ( $35.4 \pm 6.46$ individuals), then the tree phase ( $34.9 \pm 20.38$ individuals), and saplings (26.3 \pm 5.12 individuals). The Rastrococcus sp. was commonly found in the lower leaves. Scymnus sp. (Coleoptera: Coccinellidae) and Acarina (mites) were found as predator of the mealybug. This information is expected to be a reference in developing control strategies of Rastrococcus sp. especially on D. mollissimum.
\end{abstract}

Key words: attack, Dysoxylum mollissimum, growth phase, natural enemy, Rastrococcus sp.

\section{INTRODUCTION}

Dysoxylum mollissimum Blume is a fast growing tree (Ishiguri et al., 2016) that is a superior type of local timber in Bengkulu Province which famous for its quality and durability. The wood of $D$. mollissimum has a level $B$ resistance to termite, thus, this tree has a sufficient capability to survive from the assault of termite (Nuriyatin et al., 2003). The wood is cut into lumber for used in construction and furniture. As a result, the tree is widely planted and holds commodity value in Bengkulu (Depari et al., 2013a; Premono \& Lestari, 2014). Development of $D$. mollissimum cultivation is a solution to meet the needs of wood for the people in Bengkulu. Depari et al. (2013b), reported that D. mollissimum is traded in various sizes of sorts in wood depots in the city of Bengkulu.

The D. mollissimum cultivation in a vast expanse in monoculture resulted in plants susceptible to pests. Based on observations in the campus forests of Bengkulu University, Rastrococcus sp. (Hemiptera: Pseudococcidae) is one of the important pests attacking
D. mollissimum. These mealybugs cause plant growth inhibition from mild to severe. The $R$. invadens, one of Rastrococcus species, has wide host consisting 45 species from 22 families including forest trees, vegetables, shade trees, fruit trees and ornamental plants (Tanga et al., 2016). The attack of Rastrococcus sp. can harm because it sucks the liquid nutrients from plants. The $R$. invadens could spread quickly invading eastern regions of West and Central Africa causing 50-90\% damage to mangoes; moreover it also brings social and cultural problems (Tanga, 2012).

Mealybug populations in a plant habitat were influenced by host diversity, habitat conditions and seasonality (Geiger \& Daane, 2001; Walton et al., 2004). In addition, the mealybug populations in plants vary between the attacked plant parts (Khan et al., 1998). However, information about Rastrococcus sp. in D. mollissimum has never been reported. Considering this fact, it needs to perform research about the attack of Rastrococcus sp. on D. mollissimum, especially in campus forest of Bengkulu University. The purpose of this study was to evaluate the attack of Rastrococcus 
sp. on D. mollissimum in the campus forest of Bengkulu University.

\section{MATERIALS AND METHODS}

Research Site. This research was conducted at campus forest of Bengkulu University (-3\%45'30,38101"S $102^{\circ} 16^{\prime} 20,60735^{\prime \prime E}$, altitude: $\left.35.6 \mathrm{~m}\right)$ Kandang Limun, Muara Bangkahulu, Bengkulu. Identification of Rastrococcus sp. and its natural enemy was done in AprilNovember 2019 at Plant Protection Laboratory, Department of Plant Protection, Faculty of Agriculture, Bengkulu University.

Sample Collection. The sample was collected at campus forest of Bengkulu University, Kandang Limun, Muara Bangkahulu, Bengkulu in April 2019. The D. mollissimum has tree growing phases: sapling, pole and tree. On each phase, every parts of the trees was observed. The $D$. mollissimum leaf collected for Rastrococcus sp. observation was selected based on its position within the canopy (upper, lower, and middle). The observation area was one ha covering each phases of plant growth. Ten plant samples were randomly selected in each of the observation area. The D. mollissimum growing stages based on Septiawan et al. (2017) are: seedling: small tree from sprouts to height $<1,5 \mathrm{~m}$, sapling: small tree that reach $\geq 1.5 \mathrm{~m}$ in height or diameter at breast height $(\mathrm{DBH})$ $<10 \mathrm{~cm}$, pole: sapling that has DBH around $10-20 \mathrm{~cm}$, and tree: mature tree that has $\mathrm{DBH} \geq 20 \mathrm{~cm}$.

The Rastrococcus sp. samples taken from plants were put into plastic bottles containing $70 \%$ alcohol and observed under a stereo microscope. Calculation of Rastrococcus sp. population was done in the laboratory by counting the total population in all parts of the plant starting from the stem, branches and leaves of the plant.

Symptoms Observation. Symptoms observation was conducted by direct observation on selected trees for the presence of Rastrococcus sp. on each part of the tree (stems, branches and leaves). The observed symptoms then stored as a picture using a digital camera.

Rastrococcus sp. Identification. The observed Rastrococcus sp. was identified by the identification keys of Williams \& Watson (1988), Cox (1989), Williams \& de Willink (1992), and Williams (2004).

Variety of Rastrococcus sp. Population at Each Tree Growing Stage. Samples at each growing stage of D. mollissimum were ten trees. The observation variable was Rastrococcus sp. attack at each growing stage of D. mollissimum. The presence of Rastrococcus sp. on D. mollissimum was observed in all parts of the tree, i.e. on the trunk, branches, and leaves. The Rastrococcus sp. were photographed with a digital camera and the population of Rastrococcus sp. infested the plant parts were counted in the laboratory.

Host Range. Habitat and plant characteristics around D. mollissimum trees were also observed i.e. parts of leaves, branches and stems that were attacked by Rastrococcus sp.. Plants around D. mollissimum attacked by Rastrococcus sp. were also randomly observed. The Rastrococcus sp. which were found in the sorrounding plants were brought to laboratory for furhter observation. If the same Rastrococcus sp. attacking D. mollissimum were found on the surrounding plants, the plants will be categorized as a host. All samples were taken to the laboratory, then transferred to a plastic container covered with gauze.

Inventory of Natural Enemies in the Field. The presence of the natural enemies of Rastrococcus sp. was examined by performing direct observation on the D. mollissimum. The natural enemies were then collected and brought to the laboratory for further identification. The identity and total natural enemies which were found was recorded.

Data Analysis. Rastrococcus sp. infestation was calculated by counting the number of individuals found at the growth rate and affected plant parts. The data obtained from calculation of Rastrococcus sp. population were analyzed using analysis of variance (ANOVA) and Duncan test at level of 5\%.

\section{RESULTS AND DISCUSSION}

The attack of Rastrococcus sp. can be initiated by the yellowing of D. mollissimum leaves. The cell fluid of $D$. mollissimum was suctioned by this mealybugs. The leaves were also overgrown with sooty mold resulted from the secretion of Rastrococcus sp. The severe attacks on the shoots will cause in dried shoots which can inhibit growth and development of the branches (Figure 1), while straight wood is needed in this grow of the wood. The sooty mold can block the sun light causing inhibition of photosynthesis process and decrease the tree productivity. The results of this study was in line with Tanga (2012), stated that the 
attack of $R$. iceryoides causes defoliation, inhibit flower and fruit formation.

Losses due to Rastrococcus sp. infestation on pineapple have been reported in Brazil as high as 50\% (Khan et al., 1998). R. invadens caused 50-90\% loss in mango (Tanga, 2012). In addition, mealy bug pests are vectors of some plant diseases. Dysmicoccus brevipes is a vector of PMWaV virus (Pinneapple Mealybug Wilt associated Virus). Planococcus minor is a vector PYMV (Piper Yellow Mottle Virus) which reduces pepper production by $30-40 \%$ (Sihombing 2005). P. solenopsis attacked cotton caused a yield reduction of $44 \%$ in Pakistan (Dhawan et al., 2007). Ivakdalam (2010) reported that the $P$. marginatus attack on papaya can reduce fruit production in Bogor district by $58 \%$ and increase production costs by $84 \%$.

Rastrococcus sp. attack D. mollissimum, live and breed in all growth stages of the tree. The observation result showed that of the spread of Rastrococcus sp. on the plant parts of $D$. mollissimum were presented in Figure 2. The result showed that Rastrococcus sp. can be found in all parts of the D. mollissimum plant. Based on this information it can be seen that the Rastrococcus sp. can be found in all phases of the growth of D. mollissimum. Rastrococcus sp. use D. mollissimum as a shelter and food source. Waterhouse (1998) reported that Rastrococcus sp. can attack plant parts such as roots, leaves, stems and fruits. Rastrococcus sp. that live on plant seeds, can act as a source of infection in the field.

Generally, the highest number of population of Rastrococcus sp. was in the pole phase, precisely at the lower leaves ( $35.4 \pm 6.46$ individuals), then the tree phase $(34.9 \pm 20.38$ individuals $)$ and saplings $(26.3 \pm$ 5.12 individuals) (Table 1). Rastrococcus sp. prefered to live on the leaves $D$. mollissimum compared to the other plant parts because the leaves were softer than the bark or roots, so that Rastrococcus sp. could stabbed their stilets easier to suck up the liquid from the leaves D. mollissimum. The results of this study were in line with the research reported previously (Khan et al., 1998; Sether \& Hu, 2002), which stated that the D. brevipes
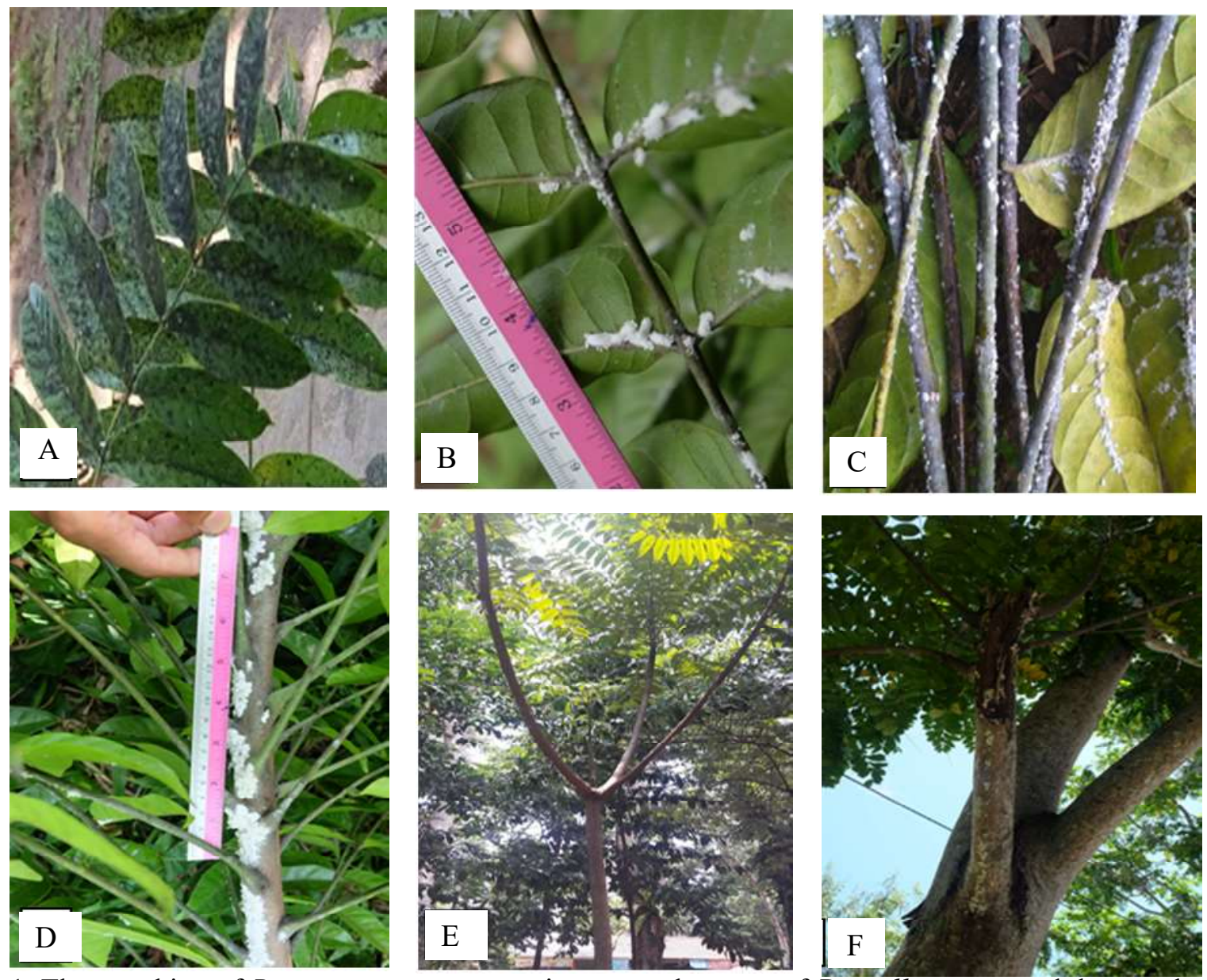

Figure 1. The attacking of Rastrococcus sp. on various growth stages of D. mollissimum and the attacked plant parts. (A) Sooty molds on attacked leaf; (B), (C) Leaves; (D) Sapling; (E) Pole; (F) Tree. 
are found mostly on the leaves. The Rastrococcus sp. population attacks on saplings, poles and trees of D. mollissimum was presented in Figure 2.

The results of this study indicated that the leaves are more suitable for the life of Rastrococcus sp. It can be seen from the population of Rastrococcus sp. that are more numerous in the leaves, especially in the older (lower) leaves. The water content, glucose, and nitrogen in the leaves are higher than those in the bark or roots (Mamahit, 2009). Moreover, the nitrogen content was sufficiently available in the older leaves so that the Rastrococcus sp. had better acces for food source. Schoonhoven et al. (1995) stated that giving the high nitrogen content to insects helps insects eat more efficiently than low nitrogen content. Rastrococcus sp. preferred to live on the underside of leaves because they would be protected from exposure of wind, rain, and natural enemy. Mealybug populations at a crop location are influenced by host diversity, habitat conditions and seasonality (Geiger \& Daane, 2001; Walton et al., 2004). In addition, the mealybug population in different plants depends on the part of the plant attacked (Khan et al. 1998) and air temperature (Chong et al., 2008). According to Gruenhagen \& Backus (1999), the population abundance and spread of pests in plants are very important to learn so that further knowing various things about its ecology. This is needed in an effort to prevent broader developments and the control efforts (Leksono et al., 2005).

The rate of Rastrococcus sp. attack on D. mollissimum trees at various growth stages was presented in Table 1. The results of the analysis of variance showed a difference in the rate of Rastrococcus sp. attack on the D. mollissimum at each growth stage. The rate of Rastrococcus sp. attack on D. mollissimum was higher in the pole phase compared to the tree and sapling phases. This result was in line with Asbani (2005). The high level of Rastrococcus sp. attack was related to the high Rastrococcus sp. population at the location, the diversity of host plants, the suitability of various physical and environmental factors for the development of the Rastrococcus sp..

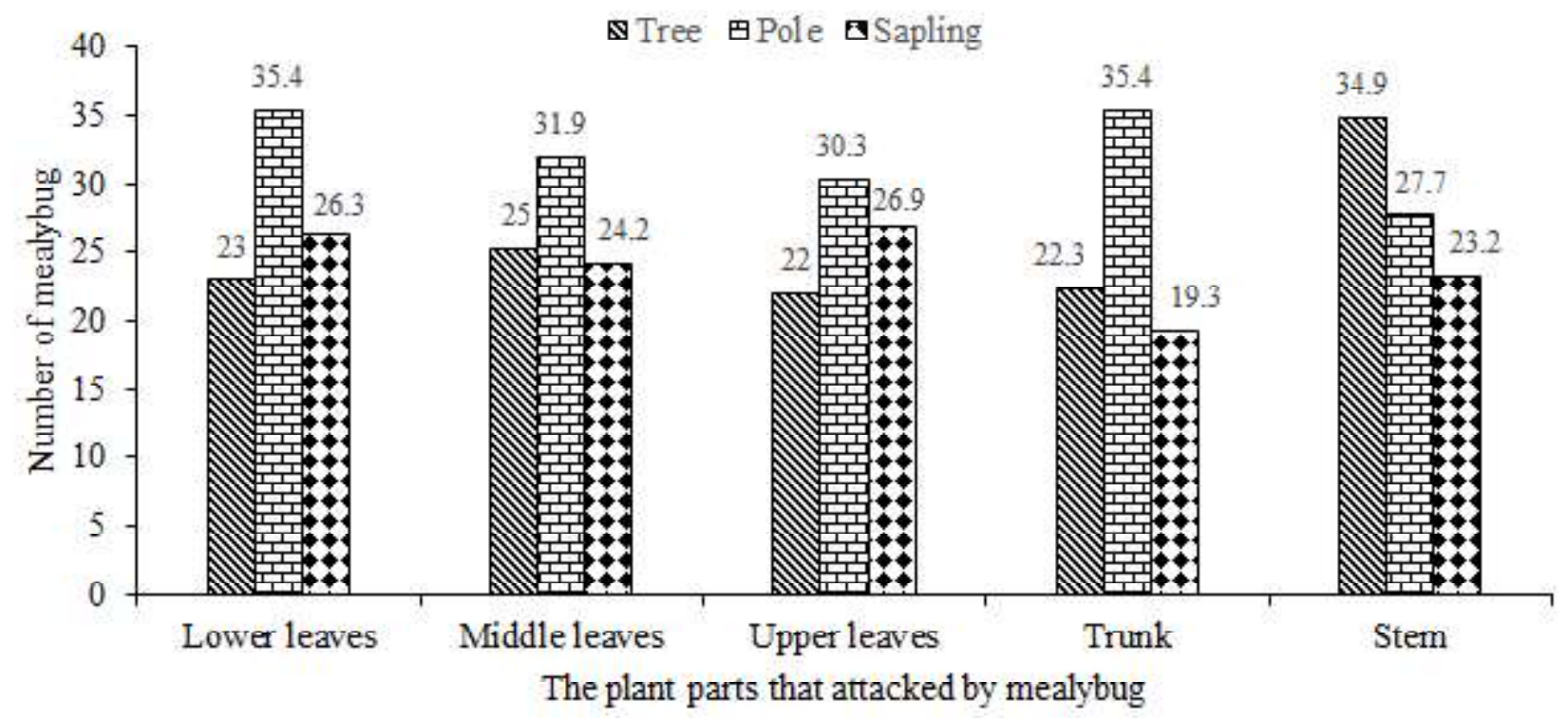

Figure 2. Number of Rastrococcus sp. on each parts of the D. mollissimum.

Table 1. The population of Rastrococcus sp. on various growth stages of D.mollissimum

\begin{tabular}{cllll}
\hline \multirow{2}{*}{ No } & Plant parts & \multicolumn{2}{c}{ Tree } & \multicolumn{2}{c}{ Pole } & \multicolumn{2}{c}{ Sapling } \\
\cline { 3 - 5 } & & \multicolumn{2}{c}{ Number of Rastrococcus sp $(\mathrm{x}) \pm \mathrm{SD}$} \\
\hline 1 & Lower leaves & $34.90 \pm 20.38 \mathrm{a}$ & $35.40 \pm 6.46 \mathrm{~b}$ & $26.30 \pm 5.12 \mathrm{a}$ \\
2 & Middle leaves & $25.30 \pm 9.49 \mathrm{a}$ & $31.90 \pm 12.46 \mathrm{a}$ & $24.20 \pm 10.20 \mathrm{a}$ \\
3 & Upper leaves & $22.00 \pm 9.69 \mathrm{a}$ & $30.30 \pm 10.58 \mathrm{a}$ & $26.40 \pm 9.32 \mathrm{a}$ \\
4 & Trunk & $22.30 \pm 10.37 \mathrm{a}$ & $35.40 \pm 7.27 \mathrm{~b}$ & $19.30 \pm 7.27 \mathrm{a}$ \\
5 & Stem & $23.00 \pm 6.63 \mathrm{a}$ & $27.70 \pm 14.12 \mathrm{a}$ & $23.20 \pm 7.25 \mathrm{a}$ \\
\hline
\end{tabular}

The number followed by same alphabet is not significantly different (Duncan test, $\alpha=5 \%$ ). 
The location of D. mollissimum in the sapling stage were surrounded by Hibiscus flowers and durian which are also hosts from the Rastrococcus sp., so that the population of Rastrococcus $\mathrm{sp}$. was higher due to the availability of host plants, and the spread of Rastrococcus sp. can occur rapidly. In Indonesia, mealybug has reported to attack various types of hosts including mangosteen (Garcinia mangostana L.), soursop (Annona muricata L.), guava (Psidium guajava L.), rambutan (Nephelium lappaceum L.), durian (Durio zibetinus L.), and duku (Lansium domesticum Corr.) (Williams, 2004).

The spread of Rastrococcus sp. could be affected by wind carried by seeds, humans, birds and other insects. The highly populated Rastrococcus $\mathrm{sp}$. and its nature as a polyphage have the potential to spread very quickly. Besides that, its biological properties can damage plants by sucking the fluids and releasing toxins, causing chlorosis, dwarf, leaf malformation, and young leaves fall. In addition, the exudates produced by Rastrococcus $\mathrm{sp}$. in the form of honey dew cause plant death (Figure 1). Thus, Rastrococcus sp. potentially cause high economic disadvantage.

The D. mollissimum bark and main stem contain chemical compounds, such as steroid, triterpenes, coumarin, lignans, flavonoids, fraxetin, scopoletin and lupeol (Almeida et al., 2002). According to Schoonhoven et al. (2005), the plants also produce secondary metabolites which play a role in the mechanism of interaction between the Rastrococcus sp. and its host. Preference or acceptance of the host in insects is influenced by the quality of macro and micro nutrients, volatile compounds, secondary metabolites, phenology, hardness, and plant resistance mechanisms (Shahid et al., 2013).

The natural enemies of Rastrococcus sp. were found in the field including predators of the order Coleoptera: Coccinellidae i.e. Scymnus sp. (Table 2), and Acarina (mites) (Figure 3). According to Sartiami et al. (2009), the natural enemies of Rastrococcus sp. are predators from the Diptera order, Syrphidae family; the Coleoptera order, Coccinellidae family, and the Neuroptera order, Chrysopidae family. The parasitoid group found was the Hymenoptera order from the Encyrtidae, Braconidae, Scelionidae, and Eulophidae families. Rastrococcus sp. predators that have been found in the Bogor and Sukabumi regions are Scymnus sp., Curinus coeruleus, Chilocorus sp. and Cryptolaemus montrouzieri. In addition, fungi are also found as entomopathogen for papaya Rastrococcus sp.. The fungus found to infect papaya Rastrococcus sp. was the member of Entomophthorales order (Sartiami et al., 2009).

Table 2. The population of Rastrococcus sp. naural enemy, Scymnus sp. larvae, on various growing stages of D. mollissimum

\begin{tabular}{|c|c|c|c|c|}
\hline \multirow{2}{*}{ No } & \multirow{2}{*}{ Plant parts } & Tree $(n=10)$ & Pole $(n=10)$ & Sapling $(\mathrm{n}=10)$ \\
\hline & & \multicolumn{3}{|c|}{ Number of Scymnus sp. larvae $(\overline{\mathrm{x}})$} \\
\hline 1 & Lower leaves & 2 & 1 & 1 \\
\hline 2 & Middle leaves & 1 & 1 & 1 \\
\hline 3 & Upper leaves & 2 & 1 & 1 \\
\hline 4 & Trunk & 2 & 1 & 1 \\
\hline 5 & Stem & 2 & 2 & 0 \\
\hline
\end{tabular}

n: Number of sample plants.
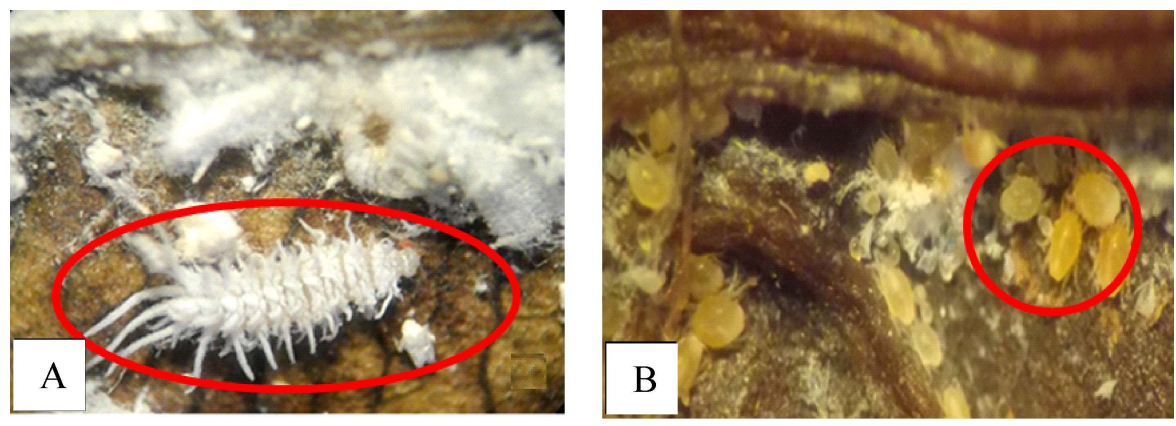

Figure 3. The Rastrococcus sp. predators. (A) Scymnus sp. eating the Rastrococcus sp.; (B) Acarina (Mites). 
The number of predators found in the field was low compared to the population of Rastrococcus sp. observed on the D. mollissimum (Table 2), thus it not able to reduce the population of Rastrococcus sp.. This situation was influenced by the presence of ants in these plants. The reciprocal relationship between ants and Rastrococcus sp. species is related to honey dew produced by Rastrococcus sp., which is an important food source for ants. The ants would eventually disrupt or kill parasitoids and predators (Tanga, 2012). Anagyrus pseudococci (Hymenoptera: Encyrtidae) is a parasitoid of $R$. iceryoides. The activity of this parasitoid is disrupted by ants Anoplolepis steingroeveri Forel (Hymenoptera: Formicidae), Crematogaster peringueyi Emery (Hymenoptera: Formicidae) and Linepithema (Maymen) (Mgocheki \& Addison, 2009). The percentage of parasitism of $R$. iceryoides by $A$. pseudococci was significantly higher without the presence of ants $(86.6 \pm 1.27 \%)$ than ants were precence $(51.4 \pm 4.13 \%)$. Ants Oecophylla longinoda provide protection to $R$. iceryoides against parasitoids and predators. The presence of $O$. longinoda has a detrimental effect on the abundance, reproductive success and oviposition strategies of female $A$. pseudococci parasitoids, which may be a limiting factor in the field conditions (Tanga et al., 2016).

\section{CONCLUSION}

The highest population of Rastrococcus $\mathrm{sp}$. were on the pole stage of D.mollissimum, reaching (35.4 \pm 6.46 individuals), then the tree stage reaching ( $34.9 \pm$ 20.38 individuals) and saplings ( $26.3 \pm 5.12$ individuals). The majority of the Rastrococcus sp. were found in the lower leaves. Scymnus sp. (Coleoptera: Coccinellidae) and Acarina (Mites) were found as predator of the mealybug. This information is expected to be a reference in developing strategies to control Rastrococcus sp. on D. mollissimum plants.

\section{ACKNOWLEDGMENT}

The author would like to thank to Bengkulu University (UNIB) for providing the financial support through the UNIB Development Research Grant 2019.

\section{REFERENCES}

Almeida EX, Conserva LM, \& Lemos RPL. 2002. Coumarins, coumarinolignoids and terpenes from Protium heptaphyllum. Biochem. Syst. Ecol. 30(7): 685-687.
Asbani N. 2005. Kelimpahan dan parasitoid kutu putih Dysmicoccus brevipes (Cockerell) (Hemiptera: Pseudococcidae) serta keanekaragaman semut pada tanaman nanas. Thesis. Institut Pertanian Bogor, Bogor.

Cox JM. 1989. The mealybug genus Planococcus (Homoptera: Pseudococcidae). Bull. br. Mus. nat. Hist. Entomol. 58(1): 1-78.

Chong JH, Roda AL, \& Mannion CM. 2008. Life history of mealybug, Maconellicoccus hirsutus (Hemiptera: Pseudococcidae) at constant temperatures. Environ. Entomol. 37(2): 323-332.

Depari EK, Istomo, \& Rusdiana O. 2013a. The effect of growth site factorand silvicultural treatment on productivity of kayu bawang (Dysoxylum mollissimum Blume) in private forest in Bengkulu. Proceedings a Forum of the Humanosphere Science School (HSS): the Dinamic Interaction between People and Ecosystems for the Future of Human Sustainability. pp. 276-283. University of Bengkulu, Bengkulu.

Depari EK, Senoaji G, \& Anggraini O. 2013b. Jenis dan ukuran sortimen kayu gergajian yang diperdagangkan di Kota Bengkulu. Prosiding Seminar Hasil Penelitian. pp. 237-242. Balai Penelitian Kehutanan, Palembang.

Dhawan AK, Singh K, Saini S, Mohindru B, Kaur A, Singh G, \& Singh S. 2007. Incidence and damage potential of mealybug, Phenacoccus solenopsis Tinsly, on cotton in Punjab. Indian J. Ecol. 34: 110-116.

Geiger CH \& Daane KM. 2001. Seasonal movement and distribution of grape mealybug (Homoptera: Pseudococcidae): developing sampling program for San Joaquin valley vineyards. J. Econ. Entomol. 94(1): 291-301.

Gruenhagen NM \& Backus EA. 1999. Diel settling pattern of female and male potato leafhoppers (Homoptera: Cicadellidae) on alfalfa. J. Econ. Entomol. 92(6): 1321-1328.

Ishiguri F, Aiso H, Hirano M, Yahya R, Wahyudi I, Ohshima J, lizuka K, \& Yokota S. 2016. Effects of radial growth rate on anatomical characteristics and wood properties of 10-year-old Dysoxylum mollissimum trees planted in Bengkulu, Indonesia. Tropics. 25(1): 23-31. 
Ivakdalam LM. 2010. Dampak ekonomi serangan hama asing invansif Paracoccus marginatus (Hemiptera: Pseudococcidae) pada usahatani pepaya di Kabupaten Bogor. Thesis. Institut Pertanian Bogor, Bogor.

Khan AA, Avesi GM, Masud SZ, \& Rizvi SWA. 1998. Incidence of mealy bug Dysmycoccus brevipes (Cockrell) on pineapple. Turk. J. Zool. 22(2): 159161.

Leksono AS, Nakagoshi N, Takada K, \& Nakamura K. 2005. Vertical and seasonal variation in the abundance and the species richness of Attelabidae and Cantharidae (Coleoptera) in a suburban mixed forest. Entomol. Sci. 8(3): 235-243.

Mamahit JME, Manuwoto S, Hidayat P, \& Sobir. 2008. Biology of mealybug Dysmicoccus brevipes Cockerel (Hemiptera: Pseudococcidae) on pineapple and lesser galangale. Bul. Littro. 19(2): 164-173.

Mgocheki N \& Addison P. 2009. Interference of ants (Hymenoptera: Formicidae) with biological control of the vine mealybug Planococcus ficus (Signoret) (Hemiptera: Pseudococcidae). Biol. Control.49(2): 180-185.

Nuriyatin N, Apriyanto E, Satriya N, \& Saprinurdin. 2003. Ketahanan lima jenis kayu berdasarkan posisi kayu di pohon terhadap serangan rayap. JIPI. 5(2): 77-82.

Premono BT \& Lestari S. 2014. Karakteristik petani dan praktek silvikultur agroforestri kayu bawang (Azadirachta excelsa (jack) M. Jacobs) di Kabupaten Bengkulu Tengah. J. Penelitian Hutan Tanaman. 11(3): 185-197.

Sartiami D, Pudjianto, \& Buchori D. 2009. Penguatan musuh alami lokal hama pendatang baru kutu putih pepaya (Paracoccus marginatus). Laporan Akhir. Fakultas Pertanian, Institut Pertanian Bogor, Bogor.

Schoonhoven LM, van Loon JJA, \& Dicke M. 2005. Insect-Plant Biology. Oxford Univ Press, New York.

Septiawan W, Indriyanto, \& Duryat. 2017. Jenis tanaman, kerapatan, dan stratifikasi tajuk pada hutan kemasyarakatan Kelompok Tani Rukun
Makmur 1 di Register 30 Gunung Tanggamus, Lampung. J. Sylva Lestari. 5(2): 88-101.

Sether DM \& Hu JS. 2002. Yield impact and spread of Pineapple mealybug wilt associated virus-2 and Mealybug wilt of pineapple in Hawaii. Plant Dis. 86(8): 867-874.

Shahid MR, Arif MJ, Khan MA, Ali A, Suhail A, Iqbal MS, Javaid M, Bibi R, Shehzad A, Khan AA, \& Khan AM. 2013. Analysis of morphological traits in different host plants associated with resistance to Phenacoccus solenopsis an invasive pest in Pakistan. Afric. J. Biotech. 11(96): 16330-16335.

Sihombing ER. 2005. Identifikasi spesies dalam famili Pseudococcidae (Ordo: Hemiptera) pada tanaman lada (Piper nigrum Linn.). Skripsi. Institut Pertanian Bogor, Bogor.

Tanga MC. 2012. Bioecology of the mango mealybug, Rastrococcus iceryoides Green (Hemiptera: Pseudococcidae) and its associated natural enemies in Kenya and Tanzania. Dissertation. University of Pretoria, Pretoria.

Tanga MC, Ekesi S, Govender P, Nderitu PW, \& Mohamed S. 2016. Antagonistic interactions between the African weaver ant Oecophylla longinoda and the parasitoid Anagyrus pseudococci potentially limits suppression of the invasive mealybug Rastrococcus iceryoides. Insects. 7(1): 1-17.

Walton VM, Daane KM, \& Pringle KL. 2004. Monitoring Planococcus ficus in South African vineyards with sex pheromone-baited traps. Crop Protect. 23(11): 1089-1096.

Waterhouse DF. 1998. Biological control of insect pests: Southeast Asian prospects Monograph. Australian Centre for International Agricultural Research, Canberra.

Williams DJ. 2004. Mealybugs of Southern Asia. The Natural History Museum. Southdene Sdn Bhd, London.

Williams DJ \& de Willink MCG. 1992. Mealybugs of Central and South America. CAB International, Wallingford.

Williams DJ \& Watson GW. 1988. The Scale Insects of the Tropical South Pasific Region. Part 2The Mealybugs. CAB International, Wallingford. 